\title{
The Analysis of Peace Teaching Practices at the University Level in Pakistan
}

\author{
* Tariq Manzoor (Corresponding Author) \\ ** Dr. Muhammad Sarwar, Professor \\ *** Ashfaque Ahmad Shah, Assistant Professor
}

\begin{abstract}
The peaceful coexistence among people is the key to a stable and progressing world. The focus of the study was to examine the desired and existing level of peace teaching practices at the university level. Convergent mixed methods design was considered best fit, using qualitative and quantitative methods. Respondents of the study were all administrators, the teachers, and BS students at the universities of Pakistan. Multistage sampling techniques were used for the selection of the respondents. Three instruments were used in this study; first and second instruments were self-developed questionnaires consisting of 50 items both for teachers and students used to collect quantitative data. The reliability of questionnaires was computed after pilot testing applying Cronbach's Alpha (0.92). The third instrument i.e. interview schedule consisted of (5) questions, was used to collect qualitative data. The analysis of data revealed that the desired level for peace teaching practices and its subsidiary values is significantly greater than the existing level of peace teaching practices. It leads to the conclusion that there is more need for teaching peace and its subsidiary values to university students. Higher Education Commission (HEC) of Pakistan may suggest a separate course on peace in its policy guidelines for the universities under its auspices.
\end{abstract}

Keywords: Peace, Peace teaching, the desired level, the existing level

\section{Introduction}

Peace education is all about teaching and learning for peace. It is more than merely learning about conflicts and their peaceful resolution. That is why peace education needs to be promoted in all parts of the world for the creation of a culture of peace (Navarro-Castro \& Nario-Galace, 2010). It will be more effective and meaningful when adopted according to the social and cultural context and aspiration of the people (Gross, 2017).

Promotion and teaching of peace to their followers have been expressed in all living religions. For example, the concept of 'Shanti' in Hinduism, 'Ahimsa' in Buddhism, the concept of 'Ping' in the Chinese language stands for harmony and realizing the unity in diversity, the 'Shalom' in Hebrew as the central concept of Christianity and Judaism which imply, peace, love, and reconciliation. Moreover, 'Salām' in Arabic is the core value of Islam. The entire life of each Muslim should be spent in its service to fulfill his religious obligation (Abubakar, 2007; Campanini, 2010; GaudefroyDemombynes, 2013; Macdonald, 2003; Navarro-Castro \& Nario-Galace, 2010).

International Organizations (UNESCO and UNICEF) have been trying to promote peace education. UNESCO has declared the years 2001 to 2010 as the International Decade for Culture of Peace in the World which aimed at developing a culture of peace by promoting education for all (SriAmnuay, 2011). Likewise, UNICEF has also launched different educational programs (United Nations International Day of Peace, Peace, and Security Agenda) for the promotion of peace education. Peace is being focused on international organizations (UNICEF, 2018).

Several values (which form the concept of Peace) have also been reflected in the objectives of the National Education Policy 2009 of Pakistan. For example, objectives 1 and 2 of the National Education Policy (2009) emphasized fulfilling the political, social, and spiritual needs of individuals, and solidification of basic ideology described in the third Constitution of Pakistan presented in 1973. Objective- 3 focused on the promotion of the desired welfare state. Objective- 4 envisioned promoting

\footnotetext{
* University of Sargodha Email: tariq_1415@yahoo.com

** Department of Education, University of Sargodha Email: drsrwr@ymail.com

*** University of Sargodha Email: multanxa@gmail.com
} 
the sense of respect for faith, religion, cultural and ethnic diversity. Objectives 5 and 6 emphasized the provision of educational facilities for each Pakistani including the minorities. Objective-20 focused on supporting the coordination and sharing of experiences and reducing disparities across the country (GOP, 2009). The peace values mentioned in the National Education Policy of Pakistan 2009 and the Vision 2025 could be accomplished only when it would have been implemented in the true letter and spirit.

It eventually calls for the inclusion of sufficient content on the peace education in the curriculum; the usage of proper teaching methods; and teachers' training to carry out peace education practices (Saeed, 2013). The proper implementation of these pre-requisites might help to produce a peaceful generation.

Educationists and activists in the field of peace education have been trying to launch peace studies in universities for the last few years. However, they focused on peace studies or peace sciences, not on the peace education (Sri-Amnuay, 2011). This situation necessitates institutionalizing peace teaching activities. But despite the recognition of peace-promoting values in the education policies, the implementation of these values has never been "at the forefront of thinking and behavior" on the part of the personals who operate the system (GOP, 2009, p.15). This uncertain situation motivated the researcher to develop and validate a module on teaching peace at the higher education level in Pakistan.

\section{Objectives of the Study}

The objective of the study was:

1. To analyze the views of heads of departments, teachers, and students about on-going peace teaching practices.

\section{The Hypothesis of the Study}

The following hypotheses were made for this study:

$\mathbf{H}_{\mathbf{0 1}}$ : There is no significant difference between the desired and the existing level of peace teaching practices in universities as perceived by the teachers and the students at universities.

$\mathbf{H}_{\mathbf{0} 2}$ : There is no significant difference between the desired and the existing level of teaching practices of the subsidiary values of peace in universities as perceived by the teachers and the students at universities.

\section{Review of Related Literature}

Peace and peace education are as old as the history of human beings. Peace had been the basic part of education systems in all societies. It had been a noble model to accomplish in all civilizations and cultures (Schumacher, 2011).

The word 'peace' is instigated from 'Pax' a Latin word. Romans used the concept of peace as 'Absentia Belli' which means warless Roman Empire (Chrystal, 2017). The Greek word 'Irene' is used as peace which means justice, harmony, and absence of any type of violence. In the same way, in Arabic 'salaam' and Hebrew 'shalom' indicates peace, love, and calmness. Likewise, in Sanskrit 'Shanti' reflects peace. In Chinese, the word 'Ping' reflects the concept of peace and harmony (Barash \& Webel, 2013).

\section{The Concept of Peace}

The concept of 'Peace' differs according to the variations of cultural context. Some people took it as an inner calmness. In a few societies, peace is meant to meet all the basic needs of individuals. Even so, peace is more than the absence of violence and war or to fulfil the basic needs of an individual but the removal of all types of injustice at all levels such as: interpersonal, personal, intergroup, national and international (McGlynn \& Zembylas, 2009; Webel \& Galtung, 2007).

\section{Beginning of Peace Education}

In history, human beings are being preached through different ways and means to resolve the conflicts and to avoid the viciousness. The process to teach the people about different methods of conflict resolution, fears of violence, and strategies for peace is called peace education (Feuchte, 2010).

Comenius (1642/1969) was one of the Europeans, who first time used the written word to promote peace education. In the seventeenth century, Czech was the educator who gave the path and universally shared the knowledge which led as the road towards peace and conflict resolution. Through this approach, this concept was developed that the ultimate goal of education was to live with peace and harmony with the diversity of culture (Bajaj, 2008). 
Peace education activities are being carried out in different communities or formally in different learning institutions. Indigenous people mostly have the traditions to resolve conflicts without using any force, just for the promotion of peace in the communities. Although in history, there is no proper written record of community-based peace education methods to improve the knowledge of the people about tactics relevant to conflict resolution (Navarro-Castro \& Nario-Galace, 2010).

Peace education grows parallel to the growth of peace movements. In the nineteenth century, after the Napoleonic war, the modern peace movement was started. Different organizations of Indigenous people were spread in different countries such as Great Britain, France, and Belgium for the promotion of peace. At the end of the nineteenth-century, peace organizations were established about all European countries and in newly formed states. In the last decade of the nineteenth century, to teach or educate about the danger of war university professors, teachers and students shaped the peace societies (Abebe \& Gbesso, 2006).

As the twentieth century begins, the people of America and Europe started the peace movement against their governments which ultimately led towards the World War I. Alfred Nobel was convinced by an Austrian Bertha von Suttner, for the establishment of a peace prize, to write novels against war and to organize legislatures internationally. The basic objective of these legislatures was to represent the notion that conflicts must be resolved through conciliation (Jäger, 2015)

In the second decade of the twentieth century, about every US state stared to promote peace through schools. Their basic purpose was to train about 5 lakh teachers about peace. Meanwhile, teachers of social studies started to teach their students about the importance of international relations. Peace educators contributed to international education reforms through which schools mean the source of providing the awareness of humanity to students. This could help to break down the national and international barriers that lead to war (Balasooriya, 2001).

Women also worked out shoulder to shoulder to men. At the beginning of the twentieth century, most of the peace leading educators were women. An American lady: Jane Addams won the Nobel Peace Prize in 1931. Her core slogan was "Peace and bread" she worked on the articulation of a vision which meant that the main cause of the war was poverty (Stomfay-Stitz, 2008).

Her contemporary Italian woman, Dr. Maria Montessori, depicts that the construction of peace depends upon education, which will free the spirit of a child, endorse the love for others and eradicate the blind obedience of authority. She highlighted that pedagogy contributes to building a peaceful world (Reardon, 2000).

The first time in 1948 "academic peace studies program" was introduced at the college level in Manchester College, Indiana, United States. After that in 1950, the peace research field was developed as "science of peace" in the contradiction of the "science of war". The threat of nuclear war in the 1980s indicated the educators of the world about future disasters. Three books were published that highlighted the threat of nuclear: "Education for Peace Birgit Brocke-Utne (1985) of Norway, Comprehensive Peace Education by Betty Reardon (1988) of the United States, and Peace Education by Ian Harris (1988)" (Brock-Utne, 1985; Reardon, 1988 and Harris, 2008).

It was argued that care, commitment, and concern should be the core values of education, and peace education must be based on universal stewardship, caring relations, and global citizenship. Focused that a universal approach of peace education should be applied in community education and at all levels of education such as elementary, secondary, and college. He also stressed that peaceful pedagogy is an essential part to teach peace.

At the end of the twentieth century, the development of peace education was an indication of an important relationship between peace movements, peace research, and peace education. These activities like to publish newsletters, holding forums, and to sponsor peace demos, give the message to teach peace education universally (Duckworth \& Allen, 2012).

\section{Aims of Peace Education}

It is evident from history that education is considered as an effective tool to tackle the violence. In the seventeenth-century Czech was the educator who explored that the basic goal of peace education was to build up a world where people can live with peace and harmony. Peace teaching means, the process to endeavor towards peace by using education (Bar-Tal and Rosen 2009). 
Peace teaching can be defined as the method of teaching learners about violence threats; it can be managed inside or outside of the classroom. This process can also be called learning about and learning for peace. Peace teaching was defined by the participants of the $3^{\text {rd }}$ African Alliance for Peace (AAP) as "the process aimed at changing mind-set from violence to peace" (Ardizzone, 2001, p. 35).

\section{Aims of Peace Teaching}

The peace teaching aims to teach the learners different skills, attitudes; and values which will be helpful for them to settle down the conflicts, non-violence, to make and maintain the relationship of love and harmony among people (Salomon, 2002).

Promotion and teaching of peace to the followers of every religion have been at the Center of all living religions. For example, the concept of 'Shanti' in Hinduism, 'Ahimsa' in Buddhism, the concept of 'Ping' in the Chinese language stands for harmony and realizing the unity in diversity, the 'Shalom' in Hebrew as the central concept of Christianity and Judaism which imply, peace, love, and reconciliation. Similarly, Salām in Arabic considered the core value of Islam. The entire life of each Muslim should be spent in its service to fulfil his religious obligation (Gaudefroy-Demombynes, 2013; Saeed, 2013 \& Thistlethwaite, 2012).

\section{History of Peace Teaching in Pakistan}

The constitution of the Islamic Republic of Pakistan 1973 emphasizes the fulfillment of the social and spiritual needs of the people of Pakistan and the solidification of basic Islamic ideology. It ultimately calls for educating a set of certain values. National Education Policy 2009 of Pakistan also addresses all the above-mentioned values in its objectives. For example, objectives 1 and 2 of the National Education Policy (2009) emphasized the fulfilling political, social, spiritual needs, and solidification of ideology described in the third Constitution of Pakistan presented in 1973. Objective-3 focused on the promotion of the desired welfare state. Objective- 4 envisioned promoting the sense of respect for each other's faith/religion and cultural/ethnic diversity. Objectives 5 and 6 emphasized the equality of educational opportunities for all Pakistani citizens including minorities. Objective-20 focused on supporting coordination and sharing of experiences and reducing disparities across provinces (Ali, 2012). Haplessly, in the past, the education system of Pakistan was unable to perform as per policy directions and serious deficiencies were observed in the accomplishment of policy guidelines e.g. lack of government interest in education and the gap between policy and its application (Aziz et al., 2014).

Peace promoting activities have been witnessed in Pakistan, particularly during the last two decades. Some of these activities include: A literary primer called 'Part Kay Barh' developed in August 1999, peace and human rights education workshop organized to prepare master trainers. It was organized in November 2000 by the curriculum wing Ministry of Education. Likewise, for the promotion of peace education, different workshops on peace education were also organized in Pakistan by the International Centre for Religion and Diplomacy (ICRD). Furthermore, in March 2009, a Pakistani organization Bargad also worked for peacebuilding with the cooperation of an international foundation, which is called Quilliam foundation. Moreover, in Pakistan with the alliance of local groups, about 200 peace poles were formed by Harmony Foundation (Durrani Sheikh, 2016; Haleem, 2013; Henri et al., 2017).

\section{Methodology \\ Research Design}

The convergent mixed methods research design was considered the best fit for this study because the nature of the study called for both qualitative and quantitative data. In this research design, both qualitative and quantitative methods of data collection are used simultaneously. The collected data were analyzed and the results were integrated thereafter. The qualitative research method is based on constructivism. This research method is embedded in the assumption that the individuals, in pursuance to understand "the world around them", try to create meanings of the experiences they undergo (Creswell 2012; Sri-Amnuay, 2011). A qualitative method was used to collect views of heads of the departments with the help of an interview schedule about peace teaching practices. Besides this, the quantitative method was also used to explore the views of university teachers and Bachelor of Science students about peace teaching practices through questionnaires. This method was employed to have an objective understanding of the existing peace teaching practices (Craig, 2005; Sri-Amnuay, 2011). 
Figure1 shows the convergent mixed method design

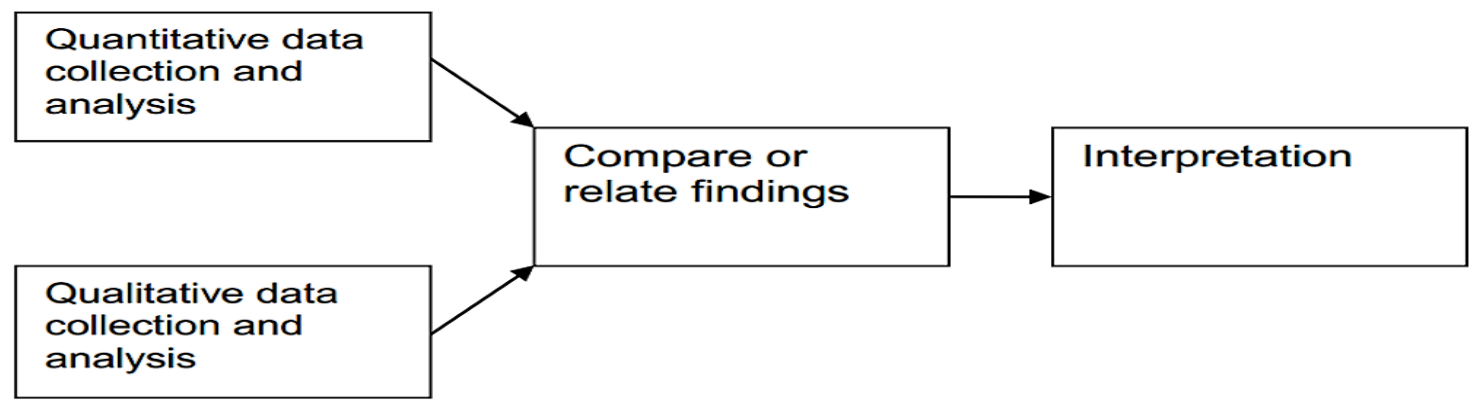

\section{The Population of the Study}

Figure 1: Convergent Mixed-method Design

All the heads of departments, the teachers, and BS students at public universities from four provinces (Punjab, Sindh, Khyber Pakhtunkhwa, and Baluchistan) of Pakistan were constituted the population of the study.

\section{Sampling}

A multistage sampling technique was used for the selection of respondents.

There are 85 general universities in Pakistan (Punjab: 33, Sindh: 22, KPK: 24 and Baluchistan: 06)

- At the first stage, $10 \%$ (but not less than two) universities were proportionately selected from all public universities of Pakistan (Punjab: 03, KPK: 02, Sindh: 02 and Baluchistan: 02), keeping in view the number of universities in each province ( 9 in total).

- Departments are divided into four major disciplines (pure sciences, social science, management, and humanities) in most of the universities of Pakistan. So, in the second stage, one department from each discipline was selected.

- In the third stage, from each selected department heads of departments, three teachers from each department and twenty-five BS students of the final year from each department were selected conveniently.

In the current study, the word 'teacher' was used for all university teachers such as lecturers, assistant professors, associate professors and professors, and 'BS' for the students of Bachelor of Science.

Table 1

\section{Respondents of the Study}

\begin{tabular}{|c|c|c|c|c|c|c|c|}
\hline \multirow{2}{*}{ Province } & \multirow{2}{*}{ University } & \multirow{2}{*}{ Respondents } & \multicolumn{4}{|c|}{ Departments } & \multirow{2}{*}{ Total } \\
\hline & & & Business Adm & Chemistry & Education & Is. Studies & \\
\hline \multirow{9}{*}{$\stackrel{\frac{0}{\sigma}}{\frac{\pi}{\Xi}}$} & \multirow{3}{*}{$\begin{array}{c}\text { University of } \\
\text { Punjab }\end{array}$} & HoDs & 01 & 01 & 01 & 01 & 04 \\
\hline & & Teachers & 06 & 01 & 04 & 05 & 16 \\
\hline & & Students & 37 & 25 & 27 & 37 & 126 \\
\hline & Bahaudin & HoDs & 01 & 01 & 01 & 01 & 04 \\
\hline & Zakaria & Teachers & 04 & 04 & 03 & 03 & 14 \\
\hline & University & Students & 21 & 54 & 29 & 20 & 124 \\
\hline & The Islamia & HoDs & 01 & 01 & 01 & 01 & 04 \\
\hline & University & Teachers & 03 & 02 & 05 & 03 & 13 \\
\hline & Bahawalpur & Students & 21 & 07 & 36 & 23 & 87 \\
\hline \multirow{6}{*}{ 疍 } & \multirow{3}{*}{$\begin{array}{c}\text { University of } \\
\text { Karachi }\end{array}$} & HoDs & 01 & 01 & 01 & 01 & 04 \\
\hline & & Teachers & 02 & 03 & 05 & 04 & 14 \\
\hline & & Students & 34 & 45 & 50 & 31 & 160 \\
\hline & \multirow{3}{*}{$\begin{array}{c}\text { Shah Abdul } \\
\text { Latif } \\
\text { University }\end{array}$} & HoDs & 01 & 01 & 00 & 01 & 03 \\
\hline & & Teachers & 00 & 05 & 03 & 00 & 08 \\
\hline & & Students & 00 & 29 & 44 & 08 & 81 \\
\hline \multirow{6}{*}{ 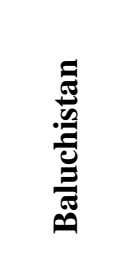 } & \multirow{6}{*}{$\begin{array}{l}\text { University of } \\
\text { Baluchistan } \\
\text { Quetta } \\
\text { Sardar } \\
\text { Bahadur } \\
\text { Khan } \\
\text { University }\end{array}$} & HoDs & 01 & 01 & 01 & 01 & 04 \\
\hline & & Teachers & 03 & 03 & 03 & 03 & 12 \\
\hline & & Students & 28 & 20 & 24 & 34 & 106 \\
\hline & & HoDs & 01 & 01 & 01 & 01 & 04 \\
\hline & & Teachers & 03 & 03 & 04 & 02 & 12 \\
\hline & & Students & 24 & 32 & 28 & 15 & 99 \\
\hline
\end{tabular}




\begin{tabular}{ccclllll}
\hline Abdul Wali & HoDs & 01 & 01 & 01 & 01 & 04 \\
\hline Khan & Teachers & 05 & 05 & 02 & 04 & 16 \\
\hline University & Students & 30 & 29 & 30 & 10 & 99 \\
\hline Hazara & HoDs & 01 & 01 & 01 & 01 & 04 \\
\hline University & Teachers & 01 & 05 & 03 & 05 & 14 \\
\hline Mansehra & Students & 23 & 19 & 28 & 15 & 85 \\
\hline
\end{tabular}

- Total: HoDs $=35$, Teachers $=119$, Students $=967$

\section{Research Instruments}

Three instruments were used in this study.

- $\quad$ semi-structured interview schedule for the heads of departments

- $\quad$ questionnaire for teachers

- $\quad$ questionnaire for students

\section{Questionnaires for Teachers and Students}

Two questionnaires were developed: one for university teachers and others for the students. The model of UNESCO-APNIEVE sourcebook 'Learning to Live Together in Peace and Harmony' (PROAP, 1998) provided the foundation for the development of the items (consisted of 9 subsidiary values and 50 sub-values). Subsidiary values formed the items of the questionnaire. Two five-point Likert-type scales were used, one was to measure the desired level and the other was to measure the existing level of peace teaching practices, ranged from, 1 (not at all) to 5 (to a great extent).

\section{A Semi-structured Interview Schedule}

A semi-structured interview schedule was developed to explore the perceptions of the heads of the departments about peace teaching practices (love, compassion, harmony, tolerance, caring and sharing, interdependence, empathy, spirituality, and gratitude) in their respective departments.

Cronbach's alpha coefficient was calculated (Cronbach, 1951) to measure the internal consistency of the questionnaires. The calculated Cronbach's alpha $(\boldsymbol{\alpha})$ values are as below:

\section{Table 2}

Alpha Reliability of Instruments 50 Items

\begin{tabular}{llccc}
\hline & Respondents & $\mathbf{N}$ & $\alpha$ (Desired) & $\alpha$ (Existing) \\
\hline 1. & University Teachers & 119 & 0.92 & 0.92 \\
2. & University Students & 967 & 0.92 & 0.92 \\
\hline
\end{tabular}
highly reliable.

In table 2: Value (0.92) if desired and existing levels shows that the research instruments were

Before starting the collection of data, the researcher sought permission from the heads of concerning departments of the sampled universities to visit the respective departments. At the outset of the interview or administration of questionnaires the researcher described the purpose of the study and introduced the various components of the research instruments with the respondents. They were also requested to allow the recording of their interviews. If someone did not allow the recording, their views were noted down.

\section{Results - Quantitative Data}

\section{Desired Level Peace Teaching Practices}

Table 3

Desired Level of Peace Teaching Practices (all Respondents)

\begin{tabular}{ccccccccc}
\hline Sr.\# & Values & \multicolumn{9}{c}{ should be taught } & \multicolumn{2}{c}{ Mean } \\
\cline { 2 - 7 } & $\begin{array}{c}\text { Not at } \\
\text { all }\end{array}$ & $\begin{array}{c}\text { To a small } \\
\text { extent } \%\end{array}$ & $\begin{array}{c}\text { To a certain } \\
\text { extent }\end{array}$ & $\begin{array}{c}\text { To a reasonable } \\
\text { extent } \\
\text { (Range } \\
1-5)\end{array}$ & Level \\
\hline 1 & Peace & 3.73 & 5.67 & 11.68 & 24.46 & 54.49 & 4.20 & High \\
\hline
\end{tabular}

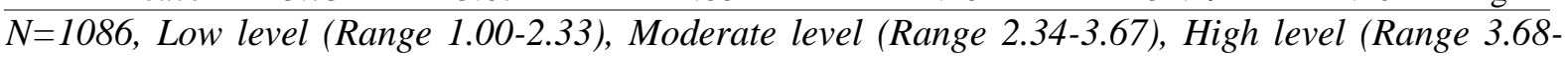
5.00)

Table 3 reflects the desired level of peace teaching practices as perceived by all respondents. Data in the table show that all respondents highly recommend peace, to be taught at the university level. The desired level of peace teaching practices was reported high $(M=4.20)$. 
Table 4

Desired Level of Peace Teaching Practices and its Subsidiary Values (all Respondents)

\begin{tabular}{|c|c|c|c|c|c|c|c|c|}
\hline \multirow[t]{2}{*}{ Sr.\# } & \multirow{2}{*}{$\begin{array}{l}\text { Values } \\
\text { 1. Peace }\end{array}$} & \multicolumn{5}{|c|}{ should be taught } & \multirow[b]{2}{*}{$\begin{array}{l}\text { Mean } \\
\text { (Range } \\
1-5)\end{array}$} & \multirow[b]{2}{*}{ Level } \\
\hline & & $\begin{array}{l}\text { Not at } \\
\text { all \% }\end{array}$ & $\begin{array}{c}\text { To a } \\
\text { small } \\
\text { extent } \%\end{array}$ & $\begin{array}{c}\text { To a } \\
\text { certain } \\
\text { extent } \%\end{array}$ & $\begin{array}{c}\text { To a } \\
\text { reasonable } \\
\text { extent } \%\end{array}$ & $\%$ & & \\
\hline 1 & Love & 5.0 & 6.18 & 12.37 & 22.77 & 53.68 & 4.14 & High \\
\hline 2 & Compassion & 4.57 & 4.88 & 9.83 & 24.20 & 56.57 & 4.24 & High \\
\hline 3 & Harmony & 4.75 & 5.42 & 11.98 & 24.43 & 53.4 & 4.16 & High \\
\hline 4 & Tolerance & 4.45 & 5.37 & 12.13 & 26.78 & 51.28 & 4.15 & High \\
\hline 5 & $\begin{array}{l}\text { Caring and } \\
\text { Sharing }\end{array}$ & 3.95 & 5.7 & 11.1 & 23.45 & 55.85 & 4.21 & High \\
\hline 6 & $\begin{array}{l}\text { Interdependen } \\
\text { ce }\end{array}$ & 4.39 & 5.68 & 11.7 & 24.07 & 54.16 & 4.18 & High \\
\hline 7 & Empathy & 2.95 & 5.45 & 10.65 & 23.45 & 57.55 & 4.28 & High \\
\hline 8 & Spirituality & 1.68 & 5.55 & 11.03 & 25.36 & 56.38 & 4.29 & High \\
\hline 9 & Gratitude & 1.85 & 6.80 & 14.30 & 25.65 & 51.50 & 4.18 & High \\
\hline & Overall & 3.73 & 5.67 & 11.68 & 24.46 & 54.49 & 4.20 & High \\
\hline
\end{tabular}

$N=1086$, Low level (Range 1.00-2.33), Moderate level (Range 2.34-3.67), High level (Range 3.685.00)

Table 4 reflects the desired level of peace teaching practices and its subsidiary values as perceived by the teachers and the students at universities (All respondents). Data in the table show that the mean score is $(M=4.20)$ which falls in the high range of mean. So, it is obvious that the respondents highly recommend the 'peace' to be taught to university students. The desired level for each of the nine subsidiary values was also reported high.

Table 5

Existing Level Peace Teaching Practices (all Respondents)

\begin{tabular}{|c|c|c|c|c|c|c|c|c|}
\hline \multirow[b]{2}{*}{ Sr.\# } & \multirow[b]{2}{*}{ Values } & \multicolumn{5}{|c|}{ being taught } & \multirow[b]{2}{*}{$\begin{array}{c}\text { Mean } \\
\text { (Range } \\
1-5)\end{array}$} & \multirow[b]{2}{*}{ Level } \\
\hline & & $\begin{array}{c}\text { Not } \\
\text { at all } \\
\%\end{array}$ & $\begin{array}{c}\text { To a } \\
\text { small } \\
\text { extent } \\
\%\end{array}$ & $\begin{array}{c}\text { To a } \\
\text { certain } \\
\text { extent } \\
\%\end{array}$ & $\begin{array}{c}\text { To a } \\
\text { reasonable } \\
\text { extent } \\
\%\end{array}$ & $\%$ & & \\
\hline 1 & Peace & 18.81 & 27.44 & 28.98 & 17.74 & 7.20 & 2.61 & Moderate \\
\hline
\end{tabular}

$N=1086$, Low level (Range 1.00-2.33), Moderate level (Range 2.34-3.67), High level (Range 3.685.00)

Table 5 shows the Existing level of peace teaching practices as perceived by both teachers and students at universities (All respondents). Data in the table show that the existing level of peace teaching practices in universities was reported at a moderate level of the mean $(\mathrm{M}=2.61)$.

Table 6

Existing Level of Peace Teaching Practices and its Subsidiary Values (all Respondents)

\begin{tabular}{|c|c|c|c|c|c|c|c|c|}
\hline \multirow[t]{2}{*}{ Sr.\# } & \multirow{2}{*}{$\begin{array}{l}\text { Values } \\
\text { 1. Peace }\end{array}$} & \multicolumn{5}{|c|}{ being taught } & \multirow[b]{2}{*}{$\begin{array}{c}\text { Mean } \\
\text { (Range } \\
1-5)\end{array}$} & \multirow[b]{2}{*}{ Level } \\
\hline & & $\begin{array}{l}\text { Not at } \\
\text { all \% }\end{array}$ & $\begin{array}{l}\text { To a small } \\
\text { extent } \%\end{array}$ & $\begin{array}{c}\text { To a } \\
\text { certain } \\
\text { extent } \%\end{array}$ & $\begin{array}{c}\text { To a } \\
\text { reasonable } \\
\text { extent } \%\end{array}$ & $\%$ & & \\
\hline 1 & Love & 21.96 & 30.26 & 28.67 & 13.48 & 6.53 & 2.54 & Moderate \\
\hline 2 & Compassion & 19.85 & 29.52 & 28.10 & 15.38 & 7.15 & 2.61 & Moderate \\
\hline 3 & Harmony & 17.27 & 30.6 & 30.18 & 14.65 & 7.3 & 2.64 & Moderate \\
\hline 4 & Tolerance & 20.4 & 30.08 & 28.68 & 14.48 & 6.38 & 2.57 & Moderate \\
\hline 5 & $\begin{array}{l}\text { Caring and } \\
\text { Sharing }\end{array}$ & 19.5 & 31.65 & 29.0 & 13.35 & 6.5 & 2.56 & Moderate \\
\hline 6 & Interdependence & 20.16 & 29.67 & 28.9 & 14.28 & 6.99 & 2.58 & Moderate \\
\hline 7 & Empathy & 15.8 & 30.3 & 28.55 & 15.3 & 10.5 & 2.74 & Moderate \\
\hline 8 & Spirituality & 17.11 & 3.58 & 29.91 & 15.54 & 6.93 & 2.65 & Moderate \\
\hline 9 & Gratitude & 17.25 & 31.3 & 28.8 & 16.2 & 6.55 & 2.64 & Moderate \\
\hline & Overall & 18.81 & 27.44 & 28.98 & 17.74 & 7.20 & 2.61 & Moderate \\
\hline
\end{tabular}

N=1086, Low level (Range 1.00-2.33), Moderate level (Range 2.34-3.67), High level (Range 3.68$5.00)$ 
Table 6 reflects the existing level of peace teaching practices and its subsidiary values as perceived by the teachers and the students at universities (All respondents). Data in the table show that, as a whole, the existing level of teaching all subsidiary values peace in universities was reported at a moderate level $(\mathrm{M}=2.54, \mathrm{M}=2.61, \mathrm{M}=2.64, \mathrm{M}=2.57, \mathrm{M}=2.56, \mathrm{M}=2.58, \mathrm{M}=2.74, \mathrm{M}=2.65$, $\mathrm{M}=2.64)$.

Table 7

The gap between Desired and Existing Level of peace Teaching Practices

\begin{tabular}{cccccccc}
\hline Sr.\# & Values & Levels & Mean & $\begin{array}{c}\text { Mean Difference } \\
\text { (Desired-Existing) }\end{array}$ & $\boldsymbol{S D}$ & $\boldsymbol{t}$ & $\boldsymbol{P}$ \\
\hline \multirow{2}{*}{1} & Peace & Desired & 4.20 & 1.67 & 1.06 & 49.76 & .000 \\
\hline
\end{tabular}

$D F=1085, p<0.05$

Table 7 reflects the gap between the desired and the existing level of peace teaching practices in universities of Pakistan as perceived by the teachers and the students at universities. A paired samples t-test was applied to test the hypothesis. The results showed that the null hypothesis that 'there is no significant difference between the desired and the existing level of peace teaching practice in universities as perceived by the teachers and the students at universities', was rejected. The existing $(M=2.60)$ level of peace teaching practices was less than the desired one $(M=4.20)$.

Table 8

The gap between Desired and Existing Level of Peace Teaching Practices and its Subsidiary Values (all Respondents)

\begin{tabular}{|c|c|c|c|c|c|c|c|}
\hline Sr.\# & Values & Levels & Mean & $\begin{array}{l}\text { Mean Difference (Desired- } \\
\text { Existing) }\end{array}$ & $S D$ & $t$ & $P$ \\
\hline & 1. Peace & & & & & & \\
\hline \multirow[t]{2}{*}{1} & Love & Desired & 4.14 & 1.60 & 1.20 & 43.90 & .000 \\
\hline & & Existing & 2.54 & & & & \\
\hline \multirow[t]{2}{*}{2} & Compassion & Desired & 4.23 & 1.63 & 1.25 & 42.84 & .000 \\
\hline & & Existing & 2.60 & & & & \\
\hline \multirow[t]{2}{*}{3} & Harmony & Desired & 4.16 & 1.52 & 1.27 & 39.33 & .000 \\
\hline & & Existing & 2.64 & & & & \\
\hline \multirow[t]{2}{*}{4} & Tolerance & Desired & 4.15 & 1.59 & 1.24 & 42.15 & .000 \\
\hline & & Existing & 2.56 & & & & \\
\hline \multirow[t]{2}{*}{5} & Caring and & Desired & 4.21 & 1.65 & 1.37 & 39.83 & .000 \\
\hline & Sharing & Existing & 2.56 & & & & \\
\hline \multirow[t]{2}{*}{6} & Interdependence & Desired & 4.18 & 1.60 & 1.14 & 45.85 & .000 \\
\hline & & Existing & 2.58 & & & & \\
\hline \multirow[t]{2}{*}{7} & Empathy & Desired & 4.27 & 1.54 & 1.45 & 34.83 & .000 \\
\hline & & Existing & 2.73 & & & & \\
\hline \multirow[t]{2}{*}{8} & Spirituality & Desired & 4.29 & 1.64 & 1.20 & 45.28 & .000 \\
\hline & & Existing & 2.65 & & & & \\
\hline \multirow[t]{4}{*}{9} & Gratitude & Desired & 4.18 & 1.55 & 1.34 & 38.09 & .000 \\
\hline & & Existing & 2.63 & & & & \\
\hline & Overall & Desired & 4.20 & & & 4076 & 000 \\
\hline & & Existing & 2.60 & 1.67 & 1.06 & 49.76 & .000 \\
\hline
\end{tabular}

$\overline{D F}=1085, p<0.05$

Table 8 indicates the gap between the desired and the existing level of teaching practices of the subsidiary values of peace, in universities of Pakistan as perceived by teachers and students at universities. A paired samples t-test was applied to test the hypothesis. The results showed that the Pvalue of all subsidiary values is less than 0.05 . so, it indicates that the null hypothesis that 'there is no significant difference between the desired and the existing level of peace teaching practices of the subsidiary values of peace in universities as perceived by the teachers and the students of universities', was rejected. The exiting level of peace teaching practices was less than the desired one.

Results - Qualitative Data

The desired level of Peace Teaching and its Subsidiary Values

The respondents unanimously stated that peace and its subsidiary values must be taught to the university students to a great extent. They were of the view that sufficient content on peace should be 
incorporated in the curriculum of all disciplines in the universities. The administrators specifically stressed upon teaching the subsidiary values of 'Love', 'Compassion', and 'Tolerance'.

Administrators described that if sufficient content on all the subsidiary values of peace is incorporated in the curriculum then the teachers will be able to manage the teaching of these values to their students. For example, one of the respondents stated,

"Mere debates, on how the peace could be taught to students, will not fulfil the very purpose. It should include some practical sort of things, from the core of heart, on what the peace is". (Respondent 4)

They further added that many of the terrorist activities are being done in the name of Islam. Unfortunately, the teenagers had been brutally exploited by the terrorists. Preventing teenagers necessitates teaching peace to young students to harmonize their attitudes and save them not being fascinated by the catchy and colourful but baseless slogans of the masked terrorists; and convince them to escape safely such entrapping trenches. One of the respondents said,

"It is direly needed to include peace in the curriculum because so many terrorist activities are being carried out in the name of Islam ... It is essential to educate our children to counterbalance these activities". (Respondent 2)

Mentioning underlying reasons for holding the stance, that the peace and its subsidiary values should be taught, they argued that Islam is the torchbearer of peace and its name is originated from the concept of peace i.e. Salaam. Stressing upon his words one among the respondents stated,

"Islam itself is the standard-bearer of peace; it is the real source of peace".

(Respondent 34)

Although most of the respondents were in favor of including peace in the curriculum, however, diversified responses were reported on the extent of its inclusion. Most of them were of the view that peace-promoting content should be included at the maximum level; a few of them were in favor of including peace up to $20 \%$ in the curriculum; three of the respondents suggested to include it up to $25 \%$ (Respondent 09,15 and 34); while, four of them recommended it to be up to $80 \%$ (Respondent 6, 15, 18 and 28).

The administrators suggested that the key themes of peace might be taught through the existing curriculum, or a specific three credit hours course may be introduced afresh. They also proposed that the additional course should be developed on a modular approach which should include specialized activities to incarnate peace values in the minds of the students. An HoD from a public university emphasized,

"A three-credit-hours course on peace should be taught to students"

(Respondent 27)

One of the respondents proposed,

"If we want to make peace as a part of the children's lives, then their training (terbiat)

is obligatory". (Respondent 5)

Existing Teaching Practices of Peace and its Subsidiary Values

When heads of departments were inquired of the existing peace teaching practices, the maximum number of the respondents believed that peace is not being taught in the universities properly. Some teachers give a moral lesson linked with peace at the beginning of their lectures.

One of the Heads of the Islamic Studies department said that the content on 'peace' already exists in many subjects. He stated that the subject of Islamic Education is taught to Muslim students while, for the non-Muslims, 'Ethics' is taught as a subject, and both of the subjects contain sufficient content on peace and its subsidiary values.

For example, the chairman of the department from a public university opined that:

In my view, peace is being taught. We have many subjects like Sociology that always talked about human rights and peace, so we have the subject of human resource management in which we always talk about peace while giving examples (Respondent-4).

Although respondents reported that peace is being taught in universities, however, varied responses were also reported on the extent of this material. For example, respondent No. 32, the dean of the Islamic Studies department of a public university, viewed.

"Although peace, as a value, is not directly being taught in the universities. However, it is part of the hidden curriculum of the university". 
On the contrary, some of the respondents were those who viewed that there is no practice of teaching 'peace' as a subject in universities. Content on peace does not exist in the curriculum. Moreover, there is no subject in peace.

One of the respondents reported that:

"We are Muslims; our religion has educated all values 1400 years ago. Strangely, we are educating non-Muslim students about values but there is no proper mechanism for teaching peace to Muslim students." (Respondent-6).

\section{Discussion}

The main objective of the study was to analyze on-going peace practices in the universities of Pakistan. The existing level of acceptance and representation of peace in learning outcomes and teaching-learning process was less than the optimal level. The representation of peace in the curriculum was less than the acceptance level. It was less in all its related values; "(love, compassion, harmony, tolerance, caring and sharing, interdependence, empathy, spirituality, and gratitude)". The results of the study were in line with the (Balasooriya, 2001) which stated that United Nations Organization (UNO) and its subsidiary bodies (e.g. UNESCO, UNICEF, etc.) have been striving for making, keeping and building peace in the world. Likewise, in Pakistan, the promotion of peace education has been emphasized in educational policies and constitutions of Pakistan. Besides this, different NGOs' are also working in Pakistan for the promotion of peace education. However, it is a matter of fact that we are still living in the era of incomparable violence in the form of crimes, injustice, war, terrorism, and exploitation.

Krueger and Malečková (2003) said that children naturally get influence by the environment and with the passage of time their behavior breeds into the next generation. The environment of educational institutions decides students' patterns of behavior. Though it is mostly believed that more education yields are less violent attitudes, there are reports of the involvement of highly educated people in violent activities and even sometimes in extremist and terrorist activities. Accordingly, it is necessary to teach peace to our students at institutional levels.

According to Sri-Amnuay (2011), educationists and activists in the field of peace education have been trying to launch peace studies in universities for the last few years. However, they focused on peace studies or peace sciences, not on peace education. This situation necessitates institutionalizing peace teaching activities. But despite the recognition of peace-promoting values in the education policies, no proper mechanism yet exists for their teaching.

\section{Conclusion}

The heads of the departments, the teachers, and the students of the universities were of the view unanimously that the desired level for teaching peace and its subsidiary values (love, compassion, harmony, tolerance, caring and sharing interdependence, empathy, spirituality, and gratitude) is significantly greater than the existing level of peace teaching practices. It leads to the conclusion that there is more need for teaching peace and its subsidiary values to university students.

\section{Recommendations}

Higher Education Commission (HEC) of Pakistan may suggest a separate course on 'peace' in its policy guidelines for the universities under its auspices.

It is recommended that the Ministry of Education may take serious and sincere steps to incorporate peace education as a regular and mandatory component of the national curriculum.

It is also recommended that an optional course on peace education may be introduced at the university level to promote these peace values.

\section{References}

Abebe, T. T. and A. Gbesso (2006). Peace education in Africa. Addis Ababa: University for Peace.

Abubakar, A. U. (2007). The Phillipines: Challenges to Peacebuilding in the GRP-MILF Peace Process. Islam and violent separatism: new democracies in Southeast Asia, Ed. A. Swain. New York: Kegan Paul.

Ali, S. (2012). Education policy borrowing in Pakistan: Public-private partnerships. Education in the broader Middle East: Borrowing a baroque arsenal: 23-40

Ardizzone, L. (2001). Towards global understanding: The transformative role of peace education. Current issues in comparative education 4(1): 1-10.

Aziz, M., Bloom, D. E., Humair, S., Jimenez, E., Rosenberg, L., \& Sathar, Z. (2014). Education system reform in Pakistan: why, when, and how? : IZA policy paper. 
Bajaj, M. (2008). Encyclopedia of peace education, IAP.

Balasooriya, A. (2001). Learning the way of peace: A teachers' guide to peace education. New Delhi: United Nations Educational, Scientific, and Cultural Organization.

Barash, D. P., and C. P. Webel (2013). Peace and conflict studies, Sage.

Bar-Tal, D., and Y. Rosen (2009). Peace education in societies involved in intractable conflicts: Direct and indirect models. Review of Educational Research 79(2), 557-575.

Brock-Utne, B. (1985). Educating for peace: A feminist perspective, Pergamon Press New York.

Campanini, M. (2010). The Qur'an: Modern Muslim Interpretations: Routledge.

Chrystal, P. (2017). Roman Women: The Women Who Influenced the History of Rome, Fonthill Media.

Craig, E. (2005). The shorter Routledge encyclopedia of philosophy, Routledge.

Creswell, J. W. (2012). Educational research: planning. Conducting, and Evaluating.

Duckworth, C. L., and B. Allen (2012). What do students learn when we teach peace? A qualitative assessment of a theater peace program. Journal of Peace Education 9(1): 81-99.

Durrani, N., Halai, A., Kadiwal, L., Rajput, S. K., Novelli, M., \& Sayed, Y. (2017). Education and social cohesion in Pakistan.

Feuchte, F. (2010). Can We Make a Difference Tomorrow?: A Systematic Evaluation of a Peace Education Programme Implemented with Liberian Refugees.

Gaudefroy-Demombynes, M. (2013). Muslim institutions: Routledge.

GOP. (2009). National Education Policy. Islamabad: Ministry of Education, Government of Pakistan Retrieved from http://unesco.org.pk/education/teachereducation/files/National\%20Education \%20Policy.pdf.

Gross, Z. (2017). Revisiting peace education: Bridging theory and practice-International and comparative perspectives-Introduction: SAGE Publications Sage UK: London, England.

Haleem, S. (2013). Pakistan-Culture Smart: The Essential Guide to Customs \& Culture, Bravo Limited.

Harris, I. (2008). History of peace education. Encyclopedia of peace education, 15-24.

Henri, M., Johnson, M. D., \& Nepal, B. (2017). A Review of Competency-Based Learning: Tools, Assessments, and Recommendations. Journal of Engineering Education, 106(4), 607-638

Jäger, U. (2015). Peace education and conflict transformation, Berghof Foundation Operations.

Macdonald, D. (2003). Curriculum change and the post-modern world: Is the school curriculum-reform movement an anachronism? Journal of curriculum studies, 35(2), 139-149.

McGlynn, C. and M. Zembylas (2009). Peace education in conflict and post-conflict societies: Comparative perspectives, Springer.

Navarro-Castro, L. and J. Nario-Galace (2010). Peace education: a pathway to the culture of peace, Center for Peace Education, Miriam College.

PROAP, U. (1998). Learning to live together in Peace and Harmony; values Education for Peace. Human Rights, Democracy, and Sustainable development for Asia-Pacific Region: a UNESCO-APENIVE Sourcebook for Teacher Education and Tertiary Level Education. Bangkok.

Krueger, A. B., \& Malečková, J. (2003). Education, poverty, and terrorism: Is there a causal connection? Journal of Economic Perspectives, 17(4), 119-144.

Reardon, B. A. (1988). Comprehensive peace education: Educating for global responsibility, ERIC.

Reardon, B. A. (2000). Peace education: A review and projection. International companion to education, $397-425$.

Saeed, A. (2013). Reading the Qur'an in the Twenty-first Century: A Contextualist Approach: Routledge.

Schumacher, E. F. (2011). Small is beautiful: A study of economics as if people mattered, Random House.

Salomon, G. (2002). The nature of peace education: Not all programs are created equal.

Sri-Amnuay, A. (2011). Developing a model of peace education in the undergraduate teacher training process

Stomfay-Stitz, A. M. (2008). 1 A History of Peace Education in the United States of America.

Thistlethwaite, S. (2012). Interfaith just peacemaking: Jewish, Christian, and Muslim perspectives on the new paradigm of peace and war, Springer.

UNICEF. (2018). Emergencies \& Humanitarian Action. Canada: United Nations of International Children Emergency Funds.

Webel, C. and J. Galtung (2007). Handbook of peace and conflict studies, Routledge. 